\title{
The Tiberian Vocalization and the Hebrew of the Second Temple Period
}

\author{
Jan Joosten, Strasbourg
}

\section{Inroduction}

While the Tiberian system of vocalization was developed only in the Middle Ages, the information encoded in the Tiberian vowels added to the Massoretic text is probably considerably older. ${ }^{1}$ Some past and present Hebraists tend to view the Massoretes themselves as the ones who created the vocalization on the basis of their general knowledge of Hebrew and the Biblical text. ${ }^{2}$ Most specialists agree, however, that the Tiberian Massoretes based their vocalization on an oral reading tradition stretching back to the time when some form of Hebrew was still a living language. ${ }^{3}$ The Tiberian vocalization preserves a host of features that could not be derived from the consonantal text, and nevertheless appear to represent genuine linguistic features of Hebrew:

- The distinction between shin and sin is not one of vocalization, but the point distinguishing them was introduced at the same time as the vowels. In some cases, Hebrew sin may have been selected so as to accord with a samekh in Aramaic, but the letter also occurs in many words not attested in that language (e.g., פשח "to strip off", שגנ "to press, drive”, שמר "to creep"). Comparative grammar shows that it is almost always correctly used in these instances as well. ${ }^{4}$

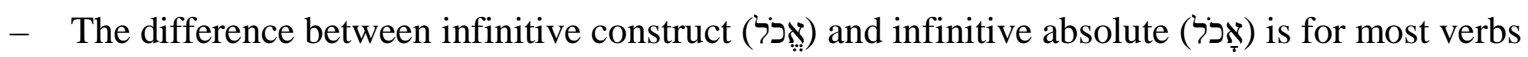
a matter of vocalization only. The distinction is not attested in the same way in Arabic, Aramaic or Rabbinic Hebrew. Nevertheless, the Massoretes get the morphology right in practically all cases.

- The distinction between long and short forms in the prefix conjugation of middle weak verbs or in the hiphil of strong verbs is another subtlety that could not be derived from Aramaic, Arabic or Rabbinic Hebrew. Admittedly, it is often in accord with the consonantal spelling-

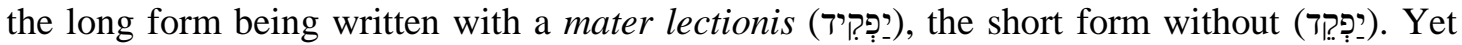
the vocalization does not blindly follow the spelling. Long forms written defectively are almost always correctly pointed by the Massoretes. ${ }^{5}$

\footnotetext{
${ }^{1}$ See S. Schorch, Die Vokale des Gesetzes. Band 1 Genesis, BZAW 339 (Berlin, De Gruyter, 2004), 1-10.

${ }^{2}$ See, e.g., P. Kahle, “Die überlieferte Aussprache des Hebräischen und die Punktation der Masoreten”, ZAW 39 (1921), 220-239; R. Bartelmus, Einführung in das Biblische Hebräisch (Zürich, Theologischer Verlag, 1994) 2022.

${ }^{3}$ See The recent review of the evidence in G. A. Khan, A Short Introduction to the Tiberian Masoretic Bible and its Reading Tradition (Piscataway NJ, Gorgias: 2012), in particular 46-48.

${ }^{4}$ See R. Steiner, “Addenda to The Case For Fricative Laterals”, in A. S. Kaye, ed., Semitic studies in honor of Wolf Leslau on the occasion of his 85th birthday, Vol 2. (Wiesbaden, Harrasowitz 1991) 1499-1514, in particular p. $1501 \mathrm{ff}$ (where earlier literature is discussed).

${ }^{5}$ See, e.g., Deut 29:22; Jud 20:16; 1 Sam 20:13; 23:22; Isa 44:28; Jer 13:16; 32:5; Ezek 46:18; Mal 3:11. An exception would be קניתו Ex 2:7, where one expects a short form.
} 
These features, and many others, can hardly have been "reconstructed" by the Massoretes on the basis of their knowledge of comparative Semitics. They must reflect an oral tradition going back to an age when the biblical idiom was still known at least to some. ${ }^{6}$

The present study will focus on some parallels and connections between Tiberian Hebrew and different varieties of Hebrew from the Second Temple period.

\section{Methodological remarks}

It is not easy to compare Tiberian Hebrew, expressed as it is in the vowel pointing, with unvocalized texts produced in the Second Temple period and earlier. Even apart from the essential incommensurability of the data, the undertaking seems daunting: Second Temple Hebrew is not a unified language, but a collection of corpora exhibiting a wide variety of linguistic forms. The language of the main sectarian scrolls from Qumran differs along dialectal lines from the Hebrew of Ben Sira, and differs again from what transpires from transcriptions of Hebrew words in the Septuagint. In addition, there are problems of attestation: some of the documents are known from old manuscripts, while others have been transmitted through a textual tradition that can only partially be retraced. How can a linguist operate with such disparate materials?

In dealing with these thorny questions it is important to keep an eye on the objective of the inquiry. The point at issue presently is the problem of the antiquity of the oral tradition leading up to the Tiberian vocalization. This issue can be discussed without having recourse to fine-grained dialectological analyses. What is of interest is not the location of Tiberian Hebrew on the dialectal spectrum of the Second Temple period, but the temporal anchoring of the tradition it represents. The perspective is historical. The question at issue is whether it is possible to find diachronic markers defining the time span when the Tiberian tradition originated. Some linguistic features spring up and die out in Hebrew at approximately datable periods. If such features can be identified in Tiberian Hebrew it will be possible to cast light on our problem.

\footnotetext{
${ }^{6}$ In his dissertation, Uri Mor has recently defended the view that the period between the Jewish wars is the one when Hebrew died out as a living language, see Uri Mor, The Grammar of the Epigraphic Hebrew Documents from Judaea between the First and the Second Revolts, Ben-Gurion University of the Negev, Beer Sheva, 2009. Note, however, that Steve Fassberg has recently enumerated some arguments for the view that Hebrew remained a spoken language in Palestine until much later, see S. Fassberg, "Which Semitic Language Did Jesus and Other Contemporary Jews Speak”, CBQ 74 (2012), 263-280, in particular 275-278.
} 


\section{Reinterpretation of forgotten words and forms}

A first category of promising features is that of forgotten words and forms. The history of Hebrew is a very long one, and many words were forgotten over time-although sometimes their meaning could later be recovered through close philological study. The phenomenon of forgotten words cannot usually be exploited in diachronic perspective: it is hard to know when the meaning of a word fell into oblivion. In a few cases, however, words that had fallen from use were then reinterpreted and used in a new meaning. The attestation of such (pseudoclassical) reinterpretation can at times be dated at least approximately. Where the reinterpretation turns up in the Tiberian pointing, it can become a diagnostic feature in the sense defined above.

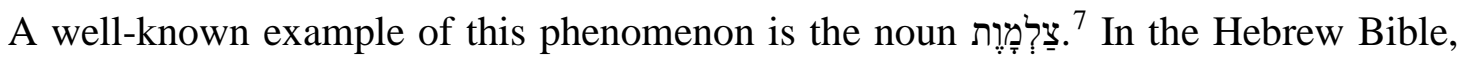
this word occurs only in poetical texts, almost always in combination with words like 7 or לפא meaning “darkness”. Its general meaning is not in doubt. But its precise interpretation has been the object of debate. According to the Tiberian vocalization (as well as the

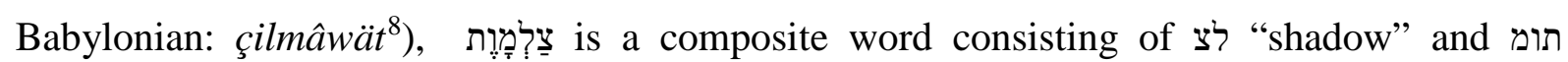
“death”. The Mechilta explains: "תומלצ והמ (in ref. to Jer 2:6)? 9 This etymology is endorsed in the lexical works of Ibn Janah and David Qimhi. By their time a derivation from the root מלצ "to be dark"-rare in Hebrew but well-known in Arabic-had been envisaged. But Ibn Janah and Qimhi argued that the pointing doesn't allow this connection. ${ }^{10}$ Eight hundred years later, Wilhelm Gesenius still held on to this traditional point of view. In the Thesaurus the word is listed under the root ללצ, with the express indication that it is a composite. ${ }^{11}$ By his time, however, critical scholars had found a way to overcome the problem of the vocalization. According to Johann Michaëlis, the noun should simply be repointed. It might originally have been pronounced șalmût (or șalmôt, or

\footnotetext{
${ }^{7}$ See C. Cohen, “The Meaning of תומלצ 'Darkness' : A Study in Philological Method”, in M. V. Fox, ed., Texts, Temples, and Traditions: A Tribute to Menahem Haran (Winona Lake IN, Eisenbrauns, 1996), 287-309.

${ }^{8}$ See I. Yeivin, The Hebrew Language Tradition as Reflected in the Babylonian Vocalization,Vol. 2 (Jerusalem, Academy of the Hebrew Language, 1985), 812.

${ }^{9}$ Mechilta d'Rabbi Ismael, ed. H. S. Horovitz, I. A. Rabin (Breslau, 1930; reprint: Jerusalem, Shalem, 1997), 154.

${ }^{10}$ Ibn Janah, Book of Hebrew Roots, ed. A. Neubauer (Oxford, Clarendon, 1875), 611; D. Qimhi, Sefer hashorashim, ed. J. H. R. Biesenthal, F. Liebrecht (Berlin, Friedländer, 1847), 313.

${ }^{11}$ G. (W.) Gesenius, Thesaurus philologicus criticus linguae hebraeae et chaldaeae veteris testament, tom. 3 (Leipzig, Vogel, 1853), 1169.
} 
șallamût). ${ }^{12}$ Over the last two hundred years, most knowledgeable scholars have adopted this opinion. Recent dictionaries agree in deriving the word from the root מלצ ${ }^{13}$ A major argument in favor of this view is that Hebrew has very few genuine composites. ${ }^{14}$ Alleged parallels such as תומרצח and are proper nouns and as such should not be used to explain a common noun. Moreover, the Ugaritic texts have provided a precise cognate in the word zlmt "darkness"-incidentally confirming the non-consonantal status of the waw in the Hebrew word. ${ }^{15}$

The upshot of these considerations is that the precise meaning of the poetic word תומלצ, originally pronounced șalmût or something similar, was, at some point in the history of Hebrew, forgotten and subsequently reinterpreted according to a type of "folk etymology" entailing a different pronunciation. It appears that the change from the original noun to the reinterpreted pseudo-composite can be dated approximately. The biblical occurrences, all reflecting the original usage of the word, take us down to the sixth century-note especially Jer 2:6 and 13:16. ${ }^{16}$ The reinterpretation, for its part, is clearly attested in the standard

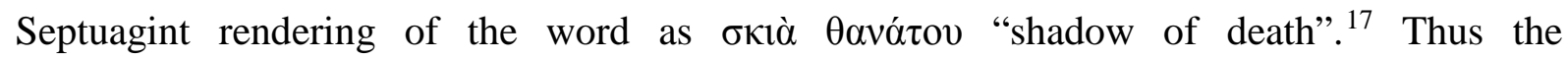
reinterpretation must have occurred between the sixth and the second century BCE. It is a reasonable hypothesis to say that the word fell into oblivion because of the disruption caused by the Judaean exile. The Tiberian vocalization reflects the later form and appears to hark back to this period. ${ }^{18}$

Another, equally famous example is the noun חפי/חיפי meaning "witness", pointed almost everywhere as if it were a form of the verb חופ "to blow.” In this case the correct

\footnotetext{
${ }^{12}$ Quoted in W. Gesenius, Hebräisch-deutsches Handwörterbuch, Theil 2 (Leipzig, Vogel, 1812), 974.

13 Thus $\mathrm{KBL}^{3}$, Gesenius ${ }^{18}$ (but not DCH).

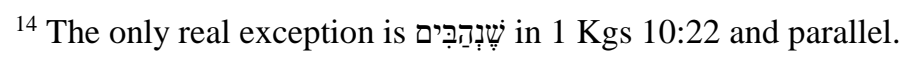

${ }^{15}$ For more details and secondary literature, see the study by Chaim Cohen quoted above in note 6.

${ }^{16}$ Some exegetes are of the opinion that the occurrences of the word in Ps 44:20 and 107:10, 14 are very late. It is hard to attain certainty in these matters.

17 This is the standard rendering everywhere except in the book of Job, where other equivalents are found as well.

${ }^{18}$ For completeness' sake it should be signaled that the word is attested once in the Qumran Scrolls: 1QHa XIII 35 תומלצב ידעב וכושיו

They hedged about me with utter darkness

It is difficult to know from this sole occurrence how the author of the Hodayoth would explain the word, let alone how he would vocalize it. In later Hebrew, the word is, unless I err, used only in reference to the biblical text.
} 
meaning of the word was retrieved only in the twentieth century after the discovery of Ugaritic. ${ }^{19}$ Otherwise, the history of this word is comparable to that of תומלצ: while the word is still used correctly by Habakkuk, at the very end of the seventh century, by the time of the Septuagint translators its meaning is completely forgotten. In the Greek version, the word is generally interpreted as a finite verb, exactly as in the MT.

These examples show, rather persuasively, that elements of the Tiberian vocalization were fixated during the Second Temple period.

\section{Grammatical modernizations}

A number of grammatical modernizations also indicate a connection between Tiberian Hebrew and the Second Temple period. Like words, grammatical forms and constructions fell into disuse over the long existence of the Hebrew language, while others arose in their place. Just as in the case of the forgotten words discussed above, some old grammatical features were later misunderstood and analyzed differently. In some instances, this reanalysis shows up in the vocalization. The old Hebrew morphology presupposed by the consonantal text is overlaid by a more recent system. Although grammatical modernizations may affect single forms, they more typically concern groups of instances, thus strengthening the case.

Several examples of possible grammatical modernization have been pointed out by various scholars, first Mayer Lambert, and after him H. L. Ginsberg, Elisha Qimron, Jeremy Hughes, David Talshir, and no doubt others. ${ }^{20}$ Some of these authors, such as Lambert and Ginsberg, loosely speak of "Rabbinic Hebrew" influence on the Massoretic pointing. But the discoveries of the Qumran texts, and subsequent research on Second Temple Hebrew show that many of the later features underlying the vocalization existed already in the Second Temple period. ${ }^{21}$ Two case studies will illustrate this point.

\footnotetext{
${ }^{19}$ See D. Pardee, “Yph ‘witness’ in Hebrew and Ugaritic”, VT 28 (1978), 204-213.

${ }^{20}$ M. Lambert, “Le waw conversif”, Revue de Études Juives 26 (1883), 47-62; idem, “L’emploi du Nifal en hébreu”, Revue de Études Juives 41 (1900), 196-214; H.L. Ginsberg, תרוסמל דעבמ, Tarbiz 5 (1934-5), 208-223; Tarbiz 6 (1935-6), 543; J. Hughes, “Post-Biblical Features of Biblical Hebrew Vocalization”, in S.E. Balentine, J. Barton, eds., Language, Theology, and the Bible. Essays in Honour of James Barr (Oxford, OUP, 1994), 6780; E. Qimron, “ארקמה ירפוס לש וושלה תרוסמ לע" in Y? Bentolila, Hadassah Shy Jubilee Book (Jerusalem, Mosad Bialik, 1997), 37-43; D. Talshir, "הקיתעה תירבעב דיחי זושלב תודעו םיבר זושלב תוחא", in M. Bar-Asher, M. Florentin, Samaritan, Hebrew And Aramaic Studies Presented to Professor Abraham Tal (Jerusalem, Bialik, 2005), 159175. See now also Khan, Short Introduction, 48-50.

${ }^{21}$ In a recent study on the form זִמִרוֹ in Biblical Hebrew, Noam Mizrahi has expressly established a link between the grammatical modernizations in the Tiberian vocalization and Second Temple Hebrew. See N. Mizrahi,
} 
A. The use of WEYIQTOL instead of WEQATAL with peh-yod verbs

In classical Hebrew prose, the two syntagms $w^{e}+$ prefix conjugation and $w^{e}+$ suffix conjugation (WEQATAL) are usually kept apart: the first expresses volition (or "light subordination”22) and teams up with the cohortative, imperative, and jussive, the second expresses more general futurity and interacts with clause-internal YIQTOL (the long form of the prefix conjugation). In other words, $w^{e}+$ prefix conjugation essentially, in classical prose, represents $w^{e}+$ jussive. The meanings and functions of the jussive are close to those of WEQATAL, but they are not identical. ${ }^{23}$

This state of affairs raises doubts as to the vocalization of the form weyira'u in the following formulaic passages:

Deut 17,13

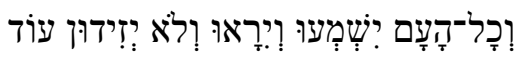

All the people will hear and be afraid, and will not act presumptuously again.

Deut 19:20

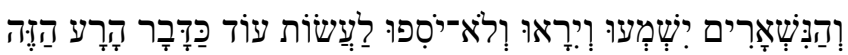

The rest shall hear and be afraid, and a crime such as this shall never again be committed.

Deut 21:21

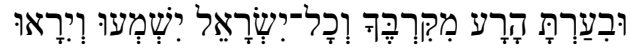

So you shall purge the evil from your midst; and all Israel will hear and be afraid.

The use of clause-internal YIQTOL in the first clause, would lead one to expect a WEQATAL form in the second clause. Functionally, none of the usual meanings of $w^{e}+$

“Colliding Traditions in Biblical Hebrew in Historical Linguistic Perspective”, in in R. I. Zer, Y. Ofer, eds., ISRAEL. Linguistic Studies in the Memory of Israel Yeivin (Jerusalem, HUBP, 2011), 341-354, xxviii [Hebrew, with English abstract].

22 JM §116, “Indirect volitive moods”.

${ }^{23}$ See J. Joosten, “Textual developments and historical linguistics” in H. Ausloos, B. Lemmelijn \& J. Trebolle Barrera, eds., After Qumran. Old and Modern Editions of the Biblical Texts - The Historical Books, Bibliotheca Ephemeridum Theologicarum Lovaniensium 246 (Leuven, Peeters 2012), 21-31; in more detail, idem, The Verbal System of Biblical Hebrew. A New Synthesis Elaborated on the Basis of Classical Prose (Jerusalem, Simor, 2012). 
jussive fits the passages well: one should hardly attribute a volitive ("and may they be afraid”) or telic ("so that they may be afraid") nuance to the second clause. These considerations may seem somewhat subjective, but they can be backed up by two more structural observations. Firstly, the cases enumerated (to which Deut 13:12 is to be added, see below) are practically the only cases of of $w^{e}+$ the prefix conjugation in the Deuteronomic Code. ${ }^{24}$ The legislative style has no place for volitive forms. Secondly, in the one instance where the Deuteronomic formula is varied in a way that puts a different verb in the second slot, WEQATAL is used instead of $w^{e}+$ prefix conjugation:

Deut 31:13

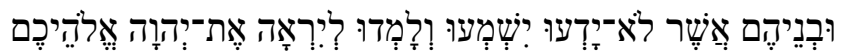

Their children, who have not known it, will hear and learn to fear the LORD your God.

All this leads up to is that instead of $w^{e}+$ prefix conjugation, the original text of Deuteronomy was intended to be read as WEQATAL in all these passages: Iִיְראוּ It appears that in the later reading tradition, the form was adapted to the syntax of post-classical Hebrew in which $w^{e}+$ YIQTOL is regularly used in legislative discourse, as is indeed the norm in Qumran Hebrew. ${ }^{25}$ First-yod verbs have the particularity that the consonantal shape of third person forms is the same for the prefix conjugation as for the suffix conjugation. This made it possible to read WEQATAL as $w^{e}+$ YIQTOL. $^{26}$

It is hard to say when the change in the reading tradition, from WEQATAL to $w^{e}+$ YIQTOL, was made. Non-volitive $w^{e}+$ YIQTOL is found already in the later biblical books, ${ }^{27}$ and is still frequent in Mishnaic Hebrew. An indication as to the relatively high date of the change is that in one or two passages, it shows up in the consonantal text as well:

\section{Deut 13:12}

\footnotetext{
${ }^{24}$ The exceptions occur in quoted direct discourse: Deut 13:3, 7, 14; 20:5, 6, 7, 8; and in a motivation clause Deut 16:19.

${ }^{25}$ See, e.g., 11QTemple VI 1-2 הלאב זוממלו הכאלמל לודגל וטקה ועמשיו . והער תא שיא אצמנה לוכ םהירוגמ לוכב וכלהתי these rules they are to govern themselves wherever they dwell, in accordance with each legal finding that bears upon communal life. Inferiors must obey their ranking superiors as regards work and wealth.”

26 The same phenomenon affects the Samaritan Pentateuch more systematically, see Joosten, "Textual developments”, 26-27.
}

${ }^{27}$ See Ezek 12:25; 14:7; 27:30; 40:42. For a full list of occurrences, see Joosten, Verbal System, 308-311. 


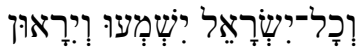

All Israel will hear and be afraid.

Although the paragogic nun is attached to the suffix conjugation once or twice, ${ }^{28}$ it typically features with the long form of the suffix conjugation. ${ }^{29}$ The addition of the nun in suggests, therefore, that the form was already read as a prefixed form. ${ }^{30}$ Similar considerations can be made in regard to another attestation of $w^{e}+$ YIQTOL of the same verb even although it does not occur in the same formula:

Deut 2:4

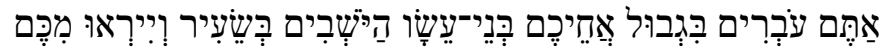

You are about to pass through the territory of your kindred, the descendants of Esau, who live in Seir. They will be afraid of you.

Here too, one expects the WEQATAL form וּיְראו: The pointing probably reflects secondary adaptation to later syntax. And here too, the consonantal text concurs with the pointing. ${ }^{31}$

The fact that the reading of the forms as prefix conjugation shows up in the consonantal text tends to indicate that the putative change from WEQATAL to $w^{e}+$ YIQTOL came about in the Second Temple period.

B. The shortening of YIQTOL when it is preceded by waw

Another case of grammatical modernization allowing a good handle on the diachronic question is the following. As Elisha Qimron has shown, Late Biblical and Qumran Hebrew tend to use the long and short forms of the prefix conjugation as syntactically conditioned

\footnotetext{
${ }^{28} \mathrm{JM} \S 42 \mathrm{f}$ (Deut 8:3, 16 ; Isa 26:16).

${ }^{29}$ See W. R. Garr, “The Paragogic nun in Rhetorical Perspective”, in S. E. Fassberg and A. Hurvitz, eds., Biblical Hebrew in Its Northwest Semitic Setting. Typological and Historical Perspectives (Jerusalem/Winona Lake, Magnes/Eisenbrauns, 2006), 65-74.

${ }^{30}$ The Samaritan Pentateuch does not attest the paragogic nun in this passage. Omission of paragogic nun is a normal phenomenon in this textual witness.

${ }^{31}$ In 4QDeut ${ }^{\text {h }}$ (4Q35), the form is written with one yod: ואריו. In the Samaritan Pentateuch, the form is written with two yods in all passages: Deut 2:4; 13:12; 17:13; 19:20; 21:21.
} 
allomorphs, the long form being used in clause-internal position, the short form at the head of the clause, particularly with waw: ${ }^{32}$

Dan 11:4

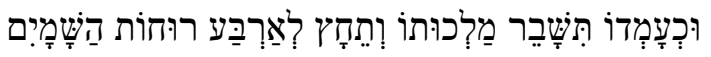

And while still rising in power, his kingdom shall be broken and divided toward the four winds of heaven.

The reason for the use of the short form וٕתחזָץ is not that the meaning is jussive-it isn't-, but simply that the form occurs at the head of the clause following waw.

The meaning of short and long forms is, in LBH, the same: both may be used over a wide range of predictive and modal statements. The LBH system is superficially similar to that of Classical Hebrew, where long and short forms tend to occur in the same syntactic positions, but in $\mathrm{CBH}$ the forms do in fact express distinct functions: the imperfect is used in predictive discourse, whereas the jussive expresses volition or "light subordination". In a context like that of Dan 11:4, Classical Hebrew would not have used the jussive but WEQATAL.

LBH grammar has affected the pointing of CBH texts in a few places where a long form has been shortened due to the prefixed waw:

\section{Ex 19:3}

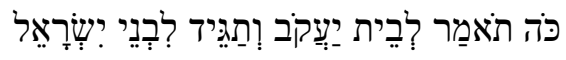

Thus shall you say to the house of Jacob, and tell the children of Israel.

In this example, the second imperfect form does not have a jussive meaning. According to the CBH system, the form should therefore be read $w^{e}$ taggîd, as is confirmed by the consonantal orthography. ${ }^{33}$ The form is to be regarded as a normal imperfect. ${ }^{34}$ It was mechanically vocalized as a jussive according to the LBH system, because it was preceded by waw. ${ }^{35}$

\footnotetext{
${ }^{32}$ See E. Qimron, “Consecutive and Conjunctive Imperfect: the Form of the Imperfect with Waw in Biblical Hebrew,” JQR 77 (1987), 151-53.

${ }^{33}$ Note also that Classical BH does not use the jussive in the second person except following the negation 'al: the second person volitive is the imperative.
} 
If this explanation is correct, the vocalization of $w^{e}+$ prefix conjugation as a short form in Ex 19:3 can only be attributed to Second Temple times. It accords with the syntax of LBH and Qumran Hebrew, but in later Hebrew the short form became obsolete.

\section{Tiberian Hebrew and the Second Temple Period}

The lexical and grammatical features inspected above show rather clearly that elements of the Tiberian vocalization hail back to the Second Temple period. By itself this is an interesting insight, establishing at once the great antiquity of the tradition on which the Massoretes based their work, and the secondary nature of some of the features this tradition incorporates.

It would be tempting to generalize this conclusion and situate the origin of the entire reading tradition leading up to the Tiberian vocalization, and the linguistic knowledge it incorporates, in this period. The time of the Second Temple is the period to which our earliest biblical manuscripts belong, the period when the biblical text became the object of intense study and commentary, the period in which we first hear of public reading of the Bible. One could easily imagine that this is also the time when more or less fixed reading traditions were established. ${ }^{36}$

Nevertheless, such a conclusion would be essentially misguided. As clear as the fact that some features of the Tiberian vocalization first emerged during the Second Temple period is the fact that precisely those features are late and secondary. Reinterpreted words and grammatical modernizations are characteristic items of Tiberian Hebrew, yet they are also exceptions proving the rule. For every "forgotten word" re-vocalized according to late exegesis Tiberian Hebrew relays innumerable old words whose morphological shape is transmitted correctly. For every construction overlaid by later grammatical rules, there are many constructions of classical Hebrew that are faithfully reproduced in the Massoretic tradition. The stream of tradition that issued in the Tiberian vowels underwent important changes in the Second Temple period, but it goes back much further. Precisely how much

\footnotetext{
${ }^{34}$ For the syntax of the passage, see J. Joosten, “A Neglected Rule and Its Exceptions: On Non-Volitive yiqtol in

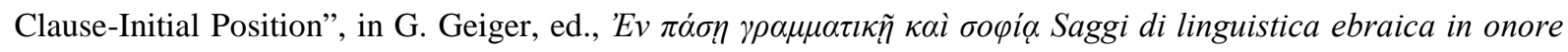
di Alviero Niccacci, ofm (Jerusalem, Franciscan Printing Press, 2011), 213-219.

35 Thus also in Mic 3:4; 6:14; Ps 85:14 (but not in Am 9:10).

${ }^{36}$ Stefan Schorch has tried to define more precisely the period when oral reading traditions of the biblical text crystallized. On the basis of an array of evidence, some of it rather loosely connected to the issue, he argues for the end of the $2^{\text {nd }}$ and the beginning of the $1^{\text {st }}$ century BCE as the most likely period when fixed reading traditions may have been established. See Schorch, Vokale des Gesetzes (above, note 1), 56-60.
} 
further is a question that cannot be addressed in the present context. ${ }^{37}$

An entirely different issue is whether the alterations introduced during the Second Temple period were the last ones that affected the reading tradition inherited by the Tiberian Massoretes. There is no reason of principle to exclude the possibility that similar changes came about even later in the stream of tradition, in late Antiquity or during the Middle Ages. Nevertheless, one will be cautious in postulating such changes. Paul Kahle famously attempted, during the nineteen twenties and thirties, to identify a number of late-and, in his view, artificial—features in the Tiberian vocalization, only to be proved spectacularly wrong by subsequent discoveries. ${ }^{38}$ Until someone brings new and better evidence, the existence of post-Second-Temple features in Tiberian Hebrew will remain a mere theoretical possibility.

\section{Conclusions}

To non-specialists the idea of an oral tradition accurately transmitting linguistic information over a millennium or more is hard to envisage. Hebrew scholars have had to adjust their critical acumen to this idea, however, because so many facts support it. Not only Tiberian Hebrew, but other traditions as well-the Babylonian vocalization, the Samaritan reading tradition-appear to link up with genuine varieties of the language from a period when it was still spoken.

Of all the vocalization systems, the Tiberian is the most extensively preserved. The evidence examined in the present paper indicates that the information it transmits is of very high quality. Although it incorporates some manifestly secondary features, the most striking of these arguably go back to the Second Temple period. Since the secondary features are to be qualified as exceptions proving the rule, much else in the Tiberian tradition would appear to be even older.

The Hebrew Bible hasn't come to us in autographs, dug up recently in archeological excavations. It has been mediated by a century-long tradition. Although the consonants and

\footnotetext{
${ }^{37} \mathrm{~A}$ few cases may be found where an opposition between CBH and LBH is expressed solely in the vocalization. Such cases seem to indicate that the vocalization of CBH texts was transmitted faithfully all the way down from pre-exilic times. See for the time being S. Morag, "On the Historical Validity of the Vocalization of the Hebrew Bible” JAOS 94 (1974), 307-315; D. Boyarin, "Towards the Talmudic Lexicon IV” Te'uda VI. Studies in Hebrew and Arabic in Memory of Dov Eron, edited by Aron Dotan (Tel Aviv, Unversity Publishing, 1988), 6375, in particular 63-64.

${ }^{38}$ See the review of the question in L. L. Grabbe, Comparative Philology and the Text of Job: A Study in Methodology (Missoula, Scholars Press, 1977), 179-197.
} 
the vocalization of this text have travelled partly along distinct itineraries, our basic attitude to them should be similar. Textual critics, exegetes, and grammarians need to adopt a critical attitude toward both the consonantal text and the vocalization: to confront variant traditions and to be prepared to admit that even when only one text form is attested it might be secondary. They also need to respect the tradition, however, and to realize to what extraordinary extent it faithfully transmits information coming to us from the mists of time. 